\title{
Optimization of biogas composition in experimental studies
}

\author{
Radostin Dimitrov ${ }^{1, *}, Z_{\text {dravko Ivanov }}{ }^{1}$, Penka Zlateva $^{2}$ and Veselin Mihaylov ${ }^{1}$ \\ ${ }^{1}$ Technical University of Varna, Department “Transport engineering and technologies”, Varna, \\ Bulgaria \\ ${ }^{2}$ Technical University of Varna, Department “Thermal engineering”, Varna, Bulgaria
}

\begin{abstract}
The article is focused on the potential and application of biogas, as an alternative fuel from Renewable Energy Sources, for use mainly in gas-generator stations. Biogas fuel is basically a mixture of methane and carbon dioxide. Its composition depends on the type of raw material used for its production. Methane concentration in biogas is between $50 \div 80 \%$. To be possible engine to work with maximum efficiency with different biogas fuels, it is necessary to modify specific adjustment parameters depending on the concentration of methane in the mixture. This requires the creation of a biogas simulation system for different concentrations of the main components.

The aim is to investigate and determine the optimum and permissible biofuel blend concentrations and their impact on engine performance and fuel consumption. Biogas can be used as a fuel to produce electricity, heat or steam or as fuel for internal combustion engine, and its use will help to reduce harmful emissions into the atmosphere.
\end{abstract}

\section{Introduction:}

The study focuses on the use and potential of biogas as an alternative fuel from renewable energy sources for use in gas generators. Studies show that the content of particulate matters and nitrogen oxides is significantly reduced. In case of burning of methane - one of the components of biogas, $\mathrm{CO}_{2}$ emissions in the atmosphere are lower. The aim is to study the impact of different concentrations of biogas on the performance and fuel consumption of automotive engines, to determine the optimum and permissible biofuel blend concentrations. For this purpose, it is necessary to create and build a system for mixing and maintaining the concentration of gases.

\section{Results and discussion:}

The use of alternative fuels is necessary due to the ever increasing standards for the content of harmful components in the exhaust gases as well as for the protection of the environment. Biogas is a gas mixture of methane and $\mathrm{CO}^{2}$. Currently in Bulgaria biogas is

\footnotetext{
* Corresponding author: r_dimitrov@tu-varna.bg
} 
not yet used as fuel for internal combustion engines, and this is a new perspective for us, while in some European countries (Germany, Sweden, Norway, etc.), Japan, China, USA and others, biogas for the drive of internal combustion engines has been used for a long time. The prospect of building biogas production and processing plants in the next ten years is becoming increasingly popular with automotive and internal combustion engines.

The composition of biogas depends on the type of raw material used for its production. Biogas is a combustible gas very similar in chemical composition to natural gas. The difference is mainly in the relative share of methane. In natural gas, the methane $\mathrm{CH}_{4}$ is about $95-97 \%$, while for biogas the relative share of methane is $50-80 \%$, which also determines calorific value of the mixture. The biogas is colorless and odorless and besides methane it also contains carbon dioxide $\left(\mathrm{CO}_{2}\right)$, nitrogen, ammonia $\left(\mathrm{NH}_{3}\right)$, sulfur dioxide $\left(\mathrm{SO}_{2}\right)$, hydrogen sulphide $\left(\mathrm{H}_{2} \mathrm{~S}\right)$, and hydrogen, depending on the raw material used. It can be used as a fuel to produce electricity, heat or steam, or as a fuel for internal combustion engine, and also its use helps to reduce harmful emissions in the atmosphere.

Table 1 shows some of the main characteristics of biogas fuel depending from raw material used for its production.

Table 1. Parameters of biogas according to raw materials

\begin{tabular}{|c|c|c|c|c|c|}
\hline Raw material & $\begin{array}{c}\text { Methane } \\
\text { content }\end{array}$ & $\mathrm{CO}_{2}$ content & $\begin{array}{l}\text { Other } \\
\text { gases }\end{array}$ & Density & $\begin{array}{c}\text { Lower heating } \\
\text { value }\end{array}$ \\
\hline & {$[\%]$} & {$[\%]$} & {$[\%]$} & {$\left[\mathrm{kg} / \mathrm{m}^{3}\right]$} & {$[\mathrm{kJ} / \mathrm{kg}]$} \\
\hline \multicolumn{6}{|c|}{ Plant raw materials } \\
\hline \multirow{2}{*}{ Corn silage } & 50,00 & 45,90 & 4,10 & 1,304 & 12724,00 \\
\hline & 55,00 & 40,90 & 4,10 & 1,242 & 15690,00 \\
\hline Beet leaves & 55,00 & 40,90 & 4,10 & 1,242 & 15690,00 \\
\hline Grass silage & 55,00 & 40,90 & 4,10 & 1,242 & 15690,00 \\
\hline \multicolumn{6}{|c|}{ Substance from the processing industry } \\
\hline \multirow{2}{*}{ Beer malt } & 55,00 & 40,90 & 4,10 & 1,242 & 14665,00 \\
\hline & 60,00 & 35,90 & 4,10 & 1,180 & 18268,00 \\
\hline \multirow{2}{*}{ Waste water } & 50,00 & 36,90 & 13,10 & 1,250 & 13250,00 \\
\hline & 60,00 & 26,90 & 13,10 & 1,126 & 19210,00 \\
\hline \multirow{2}{*}{ Forage waste } & 70,00 & 25,90 & 4,10 & 1,056 & 23812,00 \\
\hline & 75,00 & 20,90 & 4,10 & 0,994 & 27105,00 \\
\hline \multicolumn{6}{|c|}{ Organic raw materials from household waste and slaughterhouses } \\
\hline \multirow{2}{*}{$\begin{array}{l}\text { Household bio- } \\
\text { waste }\end{array}$} & 58,00 & 37,50 & 4,50 & 1,209 & 16965,00 \\
\hline & 65,00 & 30,50 & 4,50 & 1,122 & 20889,00 \\
\hline \multirow{2}{*}{ Waste fat } & 60,00 & 35,45 & 4,55 & 1,184 & 18278,00 \\
\hline & 72,00 & 23,45 & 4,55 & 1,034 & 25119,00 \\
\hline \multirow{2}{*}{$\begin{array}{l}\text { Sewage sludge } \\
\text { from sewage } \\
\text { treatment plants }\end{array}$} & 60,00 & 27,50 & 12,50 & 1,126 & 19210,00 \\
\hline & 72,00 & 15,50 & 12,50 & 0,999 & 25171,00 \\
\hline
\end{tabular}




\begin{tabular}{|l|l|l|l|l|l|} 
Liquid beef manure & 60,00 & 35,50 & 4,50 & 1,184 & 18278,00 \\
\hline $\begin{array}{l}\text { Liquid pork } \\
\text { manure }\end{array}$ & 60,00 & 35,50 & 4,50 & 1,184 & 18278,00 \\
\cline { 2 - 6 } & 70,00 & 25,50 & 4,50 & 1,059 & 23806,00 \\
\hline Bird manure & 60,00 & 35,50 & 4,50 & 1,184 & 18278,00 \\
\hline
\end{tabular}

The table shows that biogas is essentially a mixture of methane and carbon dioxide. Other gases have a very small percentage and they do not affect the combustion process. Carbon dioxide, as it is a non-combustion, ballast gas, has a major impact on biogas fuel. Its higher content in biogas has a negative impact on the calorific value of the fuel. Biogas with the highest calorific value after processing is obtained from raw materials from manure, organic household waste and some raw materials from the processing industry, and the methane content varies depending on the conditions of production.

Biogas is a fuel from a renewable energy sources that can be used in pure form as an alternative fuel for propulsion of an internal combustion engine. It is necessary to study the possibility of the engine to work steadily with this type of alternative fuel or additional actions are needed to improve its effective performance. Because biogas has a high octane rating $(\mathrm{RON}=130)$, increasing its effective engine power may get through increase its compression ratio, which may reach to $\varepsilon=13$. Using the optimal biogas fuel (depending on the raw material) for engine operation will reduce the costs incurred to get the most efficient engine performance. It is necessary to study the possibility of optimizing or determining the permissible fuel type that can be used to drive the engine and at the same time not to achieve a sharp reduction in its effective power and a significant increase in fuel consumption. The research is aimed at exploring the possibility of using not upgraded biogas to produce electricity from a gas generator station using a gas internal combustion engine. The study aims to determine the minimum acceptable concentration of methane and carbon dioxide where the engine can work steadily and provide the necessary torque needed to drive the generator. Biogas fuel upgrade technologies to reduce concentration of carbon dioxide are permissible but they are expensive, economically unprofitable and require a lot of energy.

Engines used in gas generating stations for power generation, need to be able to operate steady-state of stationary mode with a constant crankshaft rotation speed of typically 1500 min-1 or 3000 min-1, which allows the use of a lower energy fuels for engine operation. To carry out the experiment, a system is required to simulate different types of biogas fuels based on methane and carbon dioxide, and at the same time can provide gas with a constant concentration of elements in each engine operating mode.

To be possible to make experimental studies, it is necessary to create a methane and carbon dioxide mixing system. Figure 1 shows a schematic diagram of a gas mixing system, created in department "Transport engineering and technologies" in Technical University of Varna. 


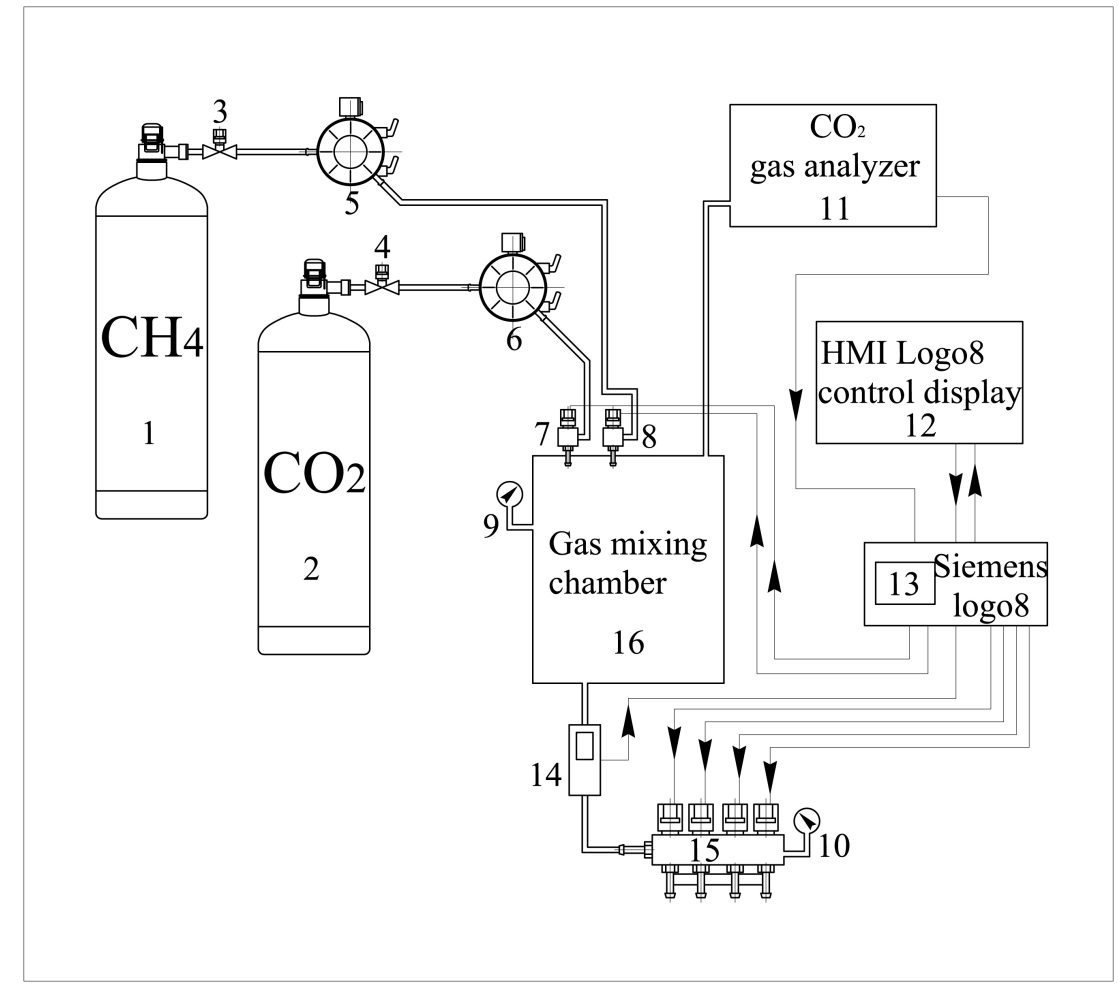

Fig. 1. System for gas mixing

The bottles for storage of methane and carbon dioxide are shown in positions 1 and 2 . Positions 3 and 4 are electro-magnetic shut-off valves controlling the flow of gases. In positions 5 and 6 are pressure regulators which reduce the pressures of the two gases and feed them to the gas injectors 7 and 8 with the same pressure, so that they can be injected into the mixing chamber 16 . The content of $\mathrm{CO}_{2}$ in the chamber is measured from the gas analyzer - pos. 11. After measuring the value of the $\mathrm{CO}_{2}$, programmable logic controller Siemens Logo8 - position 13 compares the measured value with the set concentration value and changes the injection time of the injector 7, to reach the desired concentration. A flow rate sensor - position 14 is installed at the outlet of the mixing chamber, which measures the flow rate of the gaseous mixture entering to the injector rail. Through the injectors position 15, the gas mixture is fed to the intake manifold of the internal combustion engine with the required flow and pressure for the defined mode of operation. The programmable controller sets and manages the injection time of the injectors depending on the engine operating mode. The system has the ability to mix two different gases across a wide range and different concentrations. An equal pressure of the mixture, measured by the pressure gauge 9 and 10, which can be set by the control unit, is maintained. The mixing of the gases is precise and the accuracy of the percentage ratio depends only on the accuracy of the gas analyzer. The system has the ability to deliver fuel, satisfying engine performance requirements for different RPM and load performance.

Engine experiments are made on SI engine with volume 1,275 liters, compression ratio $\varepsilon=9,75$ and nominal power $46 \mathrm{~kW}$ at $5500 \mathrm{~min}^{-1}$. The change of effective power and specific fuel consumption at external speed characteristic (maximum open throttle) at deferent concentration of methane and carbon dioxide was measured. 


\section{TE-RE-RD 2019}

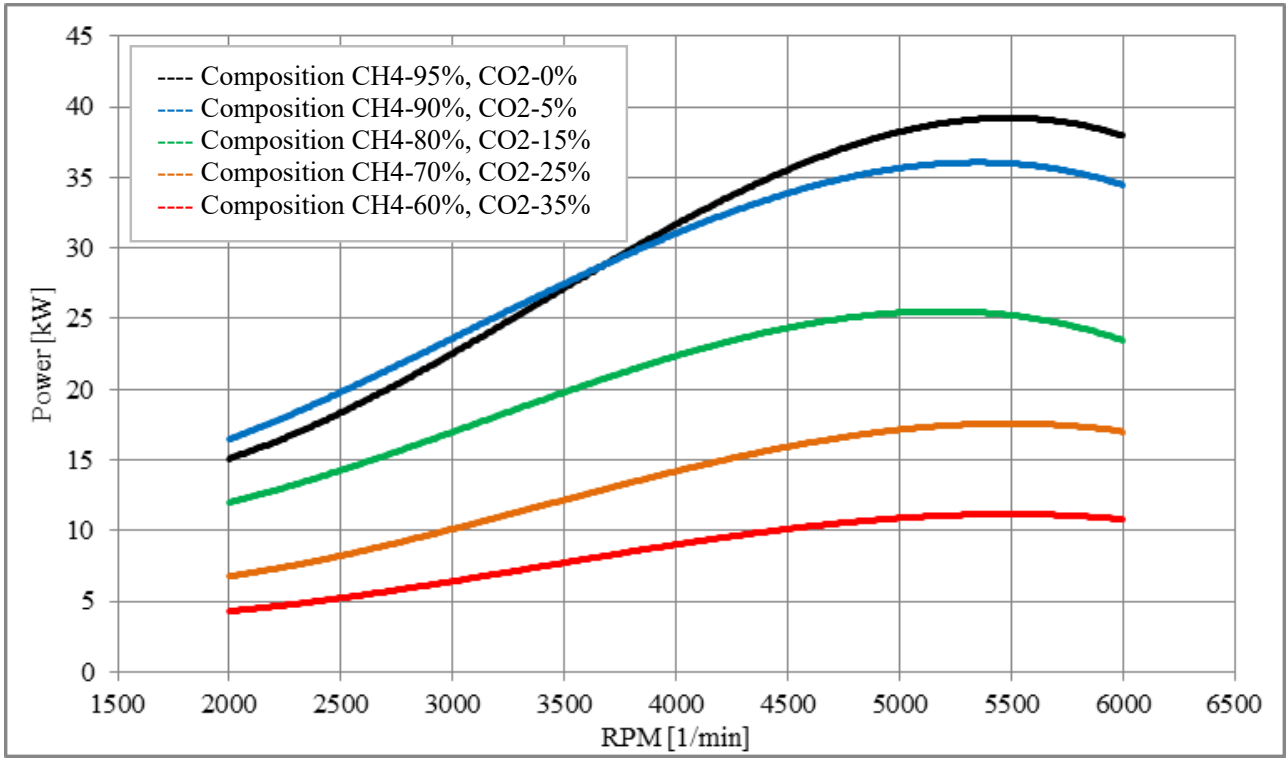

Fig. 2. Power indicators

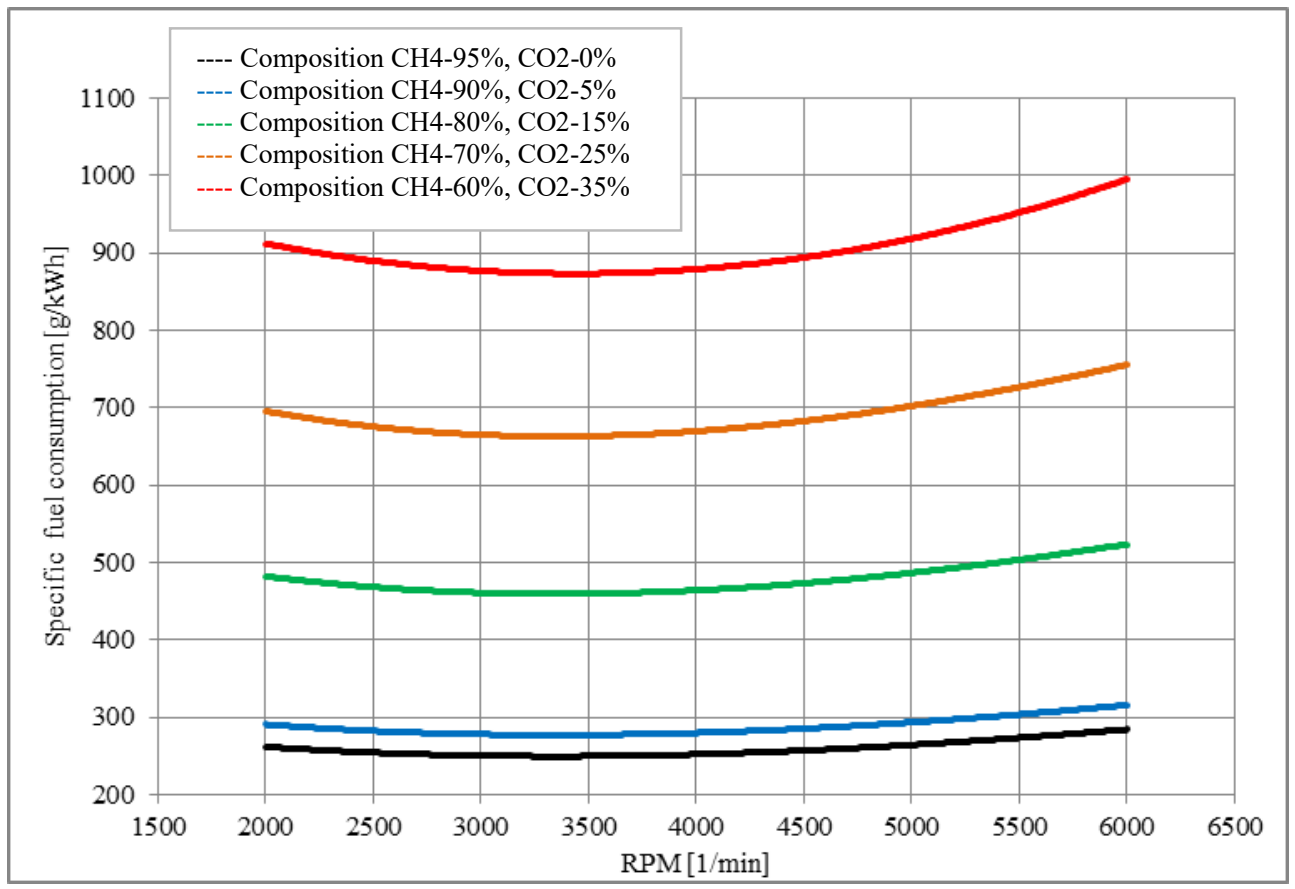

Fig. 3. Fuel consumption indicators

Variation of power and specific fuel consumption with different concentration of biogas mixtures has been investigated at wide-open-throttle operating characteristics. Figure 2 shows power variation at different concentration of biogas fuel $-95 \% \mathrm{CH}_{4}$ (upgraded biogas), $90 \% \mathrm{CH}_{4}$ and $5 \% \mathrm{CO}_{2}, 80 \% \mathrm{CH}_{4}$ and $15 \% \mathrm{CO}_{2}, 70 \% \mathrm{CH}_{4}$ and $25 \% \mathrm{CO}_{2}, 60 \% \mathrm{CH}_{4}$ and $35 \% \mathrm{CO}_{2}$. Figure 3 shows specific fuel consumption variation at different concentration of biogas fuel - $95 \% \mathrm{CH}_{4}$ (upgraded biogas), $90 \% \mathrm{CH}_{4}$ and $5 \% \mathrm{CO}_{2}, 80 \% \mathrm{CH}_{4}$ and $15 \%$ $\mathrm{CO}_{2}, 70 \% \mathrm{CH}_{4}$ and $25 \% \mathrm{CO}_{2}, 60 \% \mathrm{CH}_{4}$ and $35 \% \mathrm{CO}_{2}$. 
As the carbon dioxide content is greater in the composition of biogas, the calorific value of the fuel is lower. Optimum results are obtained when methane in biogas is about $75-80 \%$. Biogas with this content can be obtained from Forage waste or from sewage sludge.

The use of biogas with lower methane concentrations is possible, but it is necessary to improve the efficiency of the engine.

The use of biogas as a fuel for internal combustion engines has great potential with important socio-economic benefits (biogas is an alternative energy source). Its use can significantly reduce emissions of exhaust gases from the engines release in the atmosphere. In addition, biogas is a major greenhouse gas and has a high methane and carbon dioxide content of about $60 / 40 \%$. This makes mandatory the use of biogas for energy purposes in the places of its receipt (urban landfills, different farms and places of organic decay).

\section{Conclusion:}

-The system allows obtaining different concentrations of elements in the biogas composition. The mixing of the gases is precise and the accuracy of the percentage ratio depends only on the accuracy of the gas analyzer. The system has the ability to deliver fuel, satisfying engine performance requirements for different frequency and load performance.

-At reduction of concentration of methane with $15 \%$ from biogas composition, the nominal power of engine decrease with $37 \%$ from $39,7 \mathrm{~kW}$ to $24,9 \mathrm{~kW}$. At the same ratio the minimum value of specific fuel consumption increase with around $85 \%$ from 243 $\mathrm{g} / \mathrm{kWh}$ at $95 \% \mathrm{CH}_{4}$ to $448 \mathrm{~g} / \mathrm{kWh}$ at $80 \% \mathrm{CH}_{4}$ and $15 \% \mathrm{CO}_{2}$.

- $\quad$ Optimum results are obtained when methane in biogas is about $75-80 \%$. Biogas with this content can be obtained from Forage waste or from sewage sludge.

- The use of biogas with lower methane concentrations is possible, but it is necessary to improve the efficiency of the engine (for example: through increase of compression ratio of the engine).

\section{References}

1. Z. Ivanov, Dimitrov R., Mihaylov V., Petkov D.; System for regulating the composition of biogas used as fuel for internal combustion engines; PROCEEDINGS of University of Ruse, volume 57, book 4, 41-45; (2018)

2. R. Dimitrov, C. Ianasi, K. Bogdanov. Research of cycle by cycle variation of si engines working with methane as a fuel,; Annals of the "Constantin Brancusi" University of Targu-Jiu; Engineering series, 62-65, Romania, (2017)

3. R.Dimitrov, Zlateva P., Demirova S.. Investigation of the characteristics of biogas fuels and opportunities for their distribution in bulgaria; Acta technica corviniensis; Bulletin of Engineering Tome X, 69-72, Romania; (2017) http:/acta.fih.upt.ro.

4. Z. Ivanov, Mihaylov V, Kolev A. Izsledovatelska sistema za opredelyane ekologichnite haracteristiki na avtomobilni dvigateli, XVIII Nauchno-tehnicheska konferenciya $\mathrm{s}$ mejdunarodno uchastie ECO-VARNA, 511-518, Bulgaria, (2012)

5. http://agrobio.elmedia.net/bg/2013-1/editorials/

Acknowledgements

The research received funding from the National Research Program "Low Carbon Energy for the Transport and Household (E+)" of the Bulgarian Ministry of Education and Science under grant agreement DO1-214/28.11.2018 